\title{
From Rhode Island to Bavaria: Launch and Sinking of the Group 47's Founders
}

\author{
Francesca Somenzari \\ University of Turin, Turin, Italy
}

\begin{abstract}
In 1946, after a two-year imprisonment in Rhode Island, Alfred Andersch and Werner Richter (Group 47's future founders) came back to Germany as selected German citizens as a result of their cooperation with the American military authorities. In a short time, Andersch and Richter obtained a publishing license for their newspaper and so they started to act as journalists and writers within the U.S. zone of occupation. Nevertheless, American consideration and support for both of them vanished when they assumed autonomous stances concerning the future of Germany.
\end{abstract}

Keywords: Group 47, Germany, U.S. occupation, postwar, culture

\section{Introduction}

During and after WWII, the United States of America is the country permitting Europe to get rid of the totalitarian regimes and to recover from war's moral and material ashes.

How were transatlantic relationships sketched out in the postwar period? In other words, did the United States - as champions of democracy and heirs of the Wilsonianism - always give freedom to Europe, mainly to Germany (which was the core of a real reconstruction)? Or did they impose their vision and points of view by frozing some cultural initiatives? Der Ruf's experience was an impressive example of a wide system of control implemented by the Americans. Indeed culture and information became the two sectors of society more subject to check and censorship.

\section{Trusted Men}

In 1944 Alfred Andersch and Hans Werner Richter-future founders of the famous Group 47 (that is a German group gathering the postwar's main writers ${ }^{1}$ ) — were chosen by the American military authorities as representatives among those German soldiers captured and carried to prisoners camps in the United States. After being submitted to numerous interrogations useful to test their political reliability and anti-Nazi attitudes, Andersch and Richter became, in U.S. Army's eyes, trusted men to which they assign important tasks, such as the composition and coordination of an editorial staff for a newspaper printed in Rhode Island: The Call.

According to Horton,

U.S. officials were keen to determine whether Andersch might be of some special use to the Allied war effort. The earliest available documentation of interrogation results can be found in Basic Personnel Record, a standardized form used

Francesca Somenzari, Ph.D., lecturer, Department of Foreign Languages, University of Turin, Turin, Italy.

1 Heinrich Böll, Paul Celan, Günter Grass, Marcel Reich-Ranicki, and Martin Walser are the most well-known members. 
by American intelligence officers to catalog "special" prisoners. Several items from Andersch's record are of interest. On the first page of the document, which lists basic information such as height, weight, hometown, and date of capture, Andersch's spouse is listed as "Angelika (sic) Andersch", the half-Jewish women he divorced in 1943 [...]. Authorities recognized quickly that Andersch might be useful to the war effort, as reflected in the note describing him as "talkative, sincere and intelligent”. (Horton, 2011, pp. 68-69)

The newspaper was founded with the accurate aim of informing the German prisoners in the United States of what was really happening in Europe, especially the Nazi defeat. Let us read a Provost Marshal General's report concerning the paper's objectives: "a. to create a prisoner of war magazine for the broadest audience possible; b. to provide exact news of all important military and political events; c. to print news from the homeland, good reading material and entertainment" (March 17, 1945, in Records of the Office of the Provost Marshal g. 389/b. 1597, NARA, College Park).

As The Call's organizers and editors Andersch and Richter proved to be very active.

Two years later in 1946, thanks to their appreciated service in Rhode Island, Andersh and Richter were released by the U.S. Army and repatriated to Germany with a special pass guaranteeing their moral integrity: They were explicitly defined "selected citizens" (Reinhardt, 1971, p. 129).

Nevertheless, American consideration for both of them vanished when they assumed autonomous stances concerning the future of Germany.

\section{An Independent Newspaper in Bavaria}

Once arrived in Germany, at the end of 1946, Andersch and Richter received in Frankfurt a discharge card with 40 marks and some ration badges. On their identity cards the specified profession was "writer".

After a short time, thanks to American backings (Jendricke, 1988), Andersch started to write for Die Neue Zeitung/The New Journal.

According to Harold Zink, "Die Neue Zeitung/The New Journal was really not a good example of an 'overt' publication, since it was started as late as October 18, 1945, to represent American military government directly" (Zink, 1957, p. 235).

Since April 1946, together with other former prisoners of war, Andersch and Richter planned the foundation of an independent newspaper: The Call. Independent Sheets for the Young Generation. Under a regime of occupation, obtaining a license was not simple; as Jessica Gienow-Hecht reports,

According to Directive No. 4 of the military government, only people who had openly opposed the Hitler regime were to be employed in the postwar press. Journalistic abilities did not constitute a qualification. Former party members, promoters of racism or militarism, and those who had supported the NSDAP morally or materially were banned from the profession. (Gienow-Hecht, 1999, p. 38)

As trusted men of the American military authorities, in 1946 Andersch and Richter were considered journalists worth of respect and attention and so they obtained the publishing license for their The Call. Independent Sheets for the Young Generation.

\section{Aims and Topics of the Call. Independent Sheets for the Young Generation}

In spite of their above-mentioned initial collaboration with Die Neue Zeitung (The New Journal), Andersch and Richter decided to deviate from the ideological approach of that newspaper.

According to Horton, 
The Call. Independent Sheets is a description meant to distinguish the publication from "Die Neue Zeitung/The New Journal" and other official occupation newspapers by making potential readers aware that this new publication was not an instrument of the occupation regime. (Horton, 2011, pp. 125-126)

Andersch and Richter wanted their newspaper to be completely independent of any political control; topics such as unconditional surrender, German collective guilt, reeducation, socialism and market economy, Germany's occupation... had to be openly discussed by the media and by the German intelligentsia. On this specific point, Ladislao Mittner clarifies: "Right after the unconditional surrender of Germany, mainly in Richter's opinion the priority was understanding the role of the 'defeated generation', whose rebirth depended on a deep soul-searching and on a fair analysis of the situation and events” (Mittner, 1978, p. 1581).

As for the organization and the operational level, The Call. Independent Sheets was funded by the Nymphenburger Publishing House and had its office in Munich. Besides Andersch and Richter, the editorial staff was composed by journalists and writers such as Walter Kolbenhoff, Kurt Vinz, Julian Ritter, Walter Mannzen, Gustav Renè Hocke, Georg Faber, Carl-Hermann Ebbinghaus, Henry Herrmann, Horst Lange, Peter Donner, Siegfried Heldwein, Anna Maria Sora, Friedrich Minssen, Nicolaus Sombart, Walter Maria Guggenheimer, Walter Bauer, Ernst Kreuder, Heinz Friedrich, Dietrich Warnesius, Friedrich Stampfer, Walter Heist, Klaus Kulkies, Hildegard Brücher, and Frank Wischnewski. The history of German literature includes most of them under the so called "Inner Emigration" that is a large group of intellectuals who decided to remain in Germany during the Nazism and to criticize the regime in subtle ways, allegorically or by implication. As Clinefelter observes, "inner emigration was possible only for a very few artists and extremely difficult to negotiate. If their critique of the regime was too hidden, too cryptic, then their message would fail to be heard" (Clinefelter, 2014, p. 671).

The term Inner Emigration was attributed to Frank Thiess in a controversy with Thomas Mann, who suggested that any literature produced within Nazi Germany should be destroyed. In 1945, in the defense of the authors who hadn't run away from Germany, Thiess stated that "the inner emigrants did not abandon their sick mother Germany" (Thiess, 1946, p. 3).

As regards the newspaper's structure, the first eight pages were dedicated to political issues, whereas the last five ones dealt with culture and literature. The first issue appeared on August 15, 1946.

One of the most important and famous Andersch's articles was written in that first issue with the suggestive title "The Young Europe Shapes Its Face": It is an introductory manifesto for the journal. In his article, Andersch promoted the so called "social humanism" that is a moral and political philosophy at the basis of the social democracy. In his opinion, the Allied Powers of World War II should have adopted, all over the Europe, a strong policy of social reforms, such as a centralized economy and a control over industrial production against the excesses of Capitalism.

In reference to German society, Andersch stressed the need for a cooperation between Allied soldiers and German population (especially the young generations).

At the end of his reflections, he wrote "the young Europe cannot exist without a young Germany" (Neunzig, 1976, p. 19).

On the same issue of the newspaper, Andersch published a second article entitled "Essential Remarks Concerning the Nuremberg Trial": Here the author took part in a heated debate about the question of German guilt. In Andersch's vision, by fault of the decisions and political choices of the German old generation, his generation - the young one-was paying a very high prize in terms of consequences. In this regard, it's 
necessary to remember that both Andersch and Richter had been communist sympathizers before Hitler's scramble for power. Their position was definitely above suspicion.

Two months later, on October 15, 1946, in "German Prisoners of War. Lights and Shadows. A Final Outcome", Andersch recalled his experience in the United States, especially the reeducation program: In the author's opinion, local military authorities in charge of the task of reeducation had sincerely believed in its ethical aims, whereas the War Department in Washington D.C. had used the program for propaganda purposes. In this case, Andersch openly critized American policy.

Even Richter's articles had an "explosive charge", he addressed the issue of the young generations in Germany and he didn't agree with the U.S. choices. In the second issue of the newspaper, Richter published "Why Are Young Generations Silent?"; in this article, which is primarily a deep psychological analysis, the author explained that his generation had grown between the two world wars "in the hell of need and hate" (Neunzig, 1976, p. 60). As Richter wrote, "In Germany the old generation talks, whereas the young generation is silent $[\ldots]$. The young generation is silent! It is silent because it doesn't want to understand and cannot understand" (Neunzig, 1976, p. 60).

Nevertheless, in Germany the end of World War II could maybe be an opportunity for the young generation's redemption by assuming a cultural and political role; the destruction of the old generation (that is the ruling class) was one of the most important achievements of the war.

In the seventh issue, on November 15, 1946, Richter openly endorsed the political program of the Social Democratic Party, whose congress had been held in Cologne two months before: Progressive taxation, socialization of production and agricultural reform were the new keywords for an effective reorganization of society.

According to Horton,

Drawing from his communist past, Richter further defined his vision of the young generation and its role in establishing a radically different society [...]. Richter develops his idea of a new socialist society. Speaking of the young generation as one monolithic entity, much like his colleague Andersch, Richter claimed that they know that socialism has become for them a vital question. (Horton, 2011, p. 149)

\section{Conclusion}

On April 1947, Andersch and Richter were kicked out of the newspaper staff and of the editorship by decision of the American authorities in Germany. The reason given was "an excess of Nationalism" in the authors' articles.

The Call. Independent Sheets stopped permanently its publication shortly afterwards.

\section{References}

Ambrose, S., \& Bishof, G. (1992). Eisenhower and the German POWs. Facts against falsehood. Baton Rouge: Louisiana State University Press.

Andersch, A. (1948). German literature in front of a turn: An essay on the analysis of literary. Karlsruhe: Volk und Zeit.

Arnold, H. (2004). The Group 47. Hamburg: Rowohlt.

Beaumont, J. (2007). Prisoners of war in the Second World War. Journal of Contemporary History, 42(3), 535-544.

Bignami, M. (2008). An anthology of the Group 47. German writers (1947-1967). Roma: Aracne.

Böhme, K. (1973). Die deutschen Kriegsgefangenen in amerikanischer Hand: Europa. Bielefeld: Gieseking.

Boehling, R. (1996). A question of priorities: Democratic reforms and economic recovery in postwar Germany. Frankfurt,

Munich and Stuttgart under U.S. occupation 1945-1949. Providence: Berghahn. 
Bonifazio, M. (2014). The inexorable memory. Roma: Artemide.

Brockmann, S. (2004). German literary culture at the zero hour. New York: Boydell \& Brewer.

Buerger, J. (2014). Tradition versus amnesia. The Germanic Review: Literature, Culture and Theory, 89, 308-314.

Clinefelter, J. (2014). Culture in dark times. Reviewed work. Central European History, 47(3), 670-672.

Dahrendorf, R. (1967). Society and democracy in Germany. Garden City: Doubleday and Co.

Demetz, P. (1986). After the fires: Recent writing in the Germanies, Austria, and Switzerland. New York: Harcourt.

Diecks, T. (2003). Hans Werner Richter. New German Biography, 21, 530-532.

Disanto, G. (2008). 1947-1967: Twenty years of influences. The Group 47 and the establishment of a canon of German literature.

Bulletin of the Italian Association of German Studies, 1, 269-280.

Druffner, F. (2014). Education is reeducation. Peter Suhrkamp's programmatic work in cooperation with the military government in Germany. The Germanic Review: Literature, Culture and Theory, 89, 325-333.

Ermath, M. (Ed.). (1993). America and the shaping of German society, 1945-1955. Providence-Oxford: Berg.

Freschi, M. (2017). Third Reich's literature. Acireale: Bonanno.

Friedrich, C. (1948). American experiences in military government in World War II. New York: Rinehart.

Gienow-Hecht, J. (1999). Trasmission impossible. American journalism as cultural diplomacy in postwar Germany, $1945-1955$.

Baton Rouge: Louisiana State University Press.

Goedde, P. (2003). GIs and Germans: Culture, gender and foreign relations, 1945-1949. New Haven: Yale University Press.

Hastings, J. (1976). Die Akten des office of military government for Germany. Quarterly Notebooks for Contemporary History, $24,75-101$.

Hermand, J. (2013). Culture in dark times: Nazi fascism, inner emigration, and exile. New York and Oxford: Berghahn Books.

Horton, A. (2011). The long road home: Alfred Andersch, Hans Werner Richter and the German search for meaning in catastrophe. Johnson City: East Tennessee State University Press.

Horton, A. (2005). Catastrophe and identity in post-war German literature. Johnson City: East Tennessee State University Press. Jendricke, B. (1988). Alfred Andersch. Amburgo: Rowohlt.

Jones Mumford, H. (1972). Guide to American literature and its backgrounds since 1890. Cambridge: Harvard University Press.

Junker, D. (2004). The United States and Germany in the era of the Cold War, 1945-1990, Vols. I-II. Washington D.C.: German Historical Institute.

Kroell, F. (1979). The Group 47. Stuttgart: Metzler.

Lettau, R. (Ed.). (1967). The Group 47. Berlin: Luchterhand.

MacDonogh, G. (2009). After the Reich: The brutal history of the allied occupation. New York: Basic.

Mandel, S. (1973). Group 47: The reflected intellect. Carbondale: Southern Illinois University Press.

Merritt, R. (1995). Democracy imposed. Occupation policy and the German public 1945-1949. New Haven: Yale University Press. Mittner, L. (1978). History of German literature, Vol. III. Turin: Einaudi.

NARA, College Park. (March 17, 1945). Records of the Office of the Provost Marshal g. 389/b. 1597.

Neunzig, H. A. (Ed.). (1976). The call. Independent sheets for the young generation. A selection. Munich: Nymphenburger.

Neunzig, H. A. (1979). Hans Werner Richter and the Group 47. Munich: Nymphenburger.

Niven, B. (2002). Facing the Nazi past. London: Routledge.

Parkes, S. (1986). Writers and politics in west Germany. London: Croom Helm.

Parkes, S., \& White, J. (Eds.). (1999). The Group 47 fifty years on a re-appraisal of its literary and political significance. Amsterdam-Atlanta: Rodopi.

Pronay, N., \& Wilson, K. (Eds.). (1985). The political re-education of Germany and her allies after World War II. London: Croom Helm.

Reinhardt, S. (1971). Alfred Andersch: A biography. Zurich: Diogenes.

Richter, H. W. (Ed.). (1962). Almanac of Group 47. Hamburg: Rowohlt.

Ritter, G. (1965). The German problem: Basic questions of German political life. Past and present. Columbus: Ohio State University Press.

Robin, R. (2001). The barbed-wire college: Reeducating German POWs in the United States during World War II. Princeton: Princeton University Press.

Schlant, E., \& Rimer, T. J. (Eds.). (1991). Legacies and ambiguities: Postwar fiction and culture in West Germany and Japan. Washington D.C.: Woodrow Wilson Center Press.

Schmitter Heisler, B. (2013). From German prisoner of war to American citizen. Jefferson: McFarland. 
Schwab-Felisch, H. (Ed.). (1962). The call. A newspaper in post-war Germany. Munich: Dtv.

Schwartz, T. A. (1991). America's Germany. John Mc Cloy and the Federal Republic of Germany. Cambridge: Harvard University Press.

Smith, J. (1998). Alfred Andersch's experiences as a prisoner of war in America. Ann Arbor: UMI.

Somenzari, F. (2011). German prisoners of war in American hand: Germany (1945-1947). Turin: Zamorani.

Somenzari, F. (2013). September 8, 1943, and the Italian armistice. Italian prisoners of war in the United States. Roma: Aracne.

Stern, F. (1974). The politics of cultural despair: A study in the rise of the Germanic ideology. Berkeley: University of Carolina Press.

Thiess, F., Mann, T., \& von Molo, W. (1946). A debate on the outer and inner emigration. Dortmund: Druckschriften Vertriebsdienst.

Van Der Will, W. (1997). From the 1940s to the 1990s. The critical intelligentsia's changing role in the political culture of the Federal Republic. Review of Contemporary German Affairs, 5(1), 25-48.

Wegner, G., \& Fuessl, K. H. (1997). Wissenschaft als säkularer Kreuzzug: Thomas V. Smith und die deutschen Kriegsgefangenen in den USA (1944-1946). Paedagogica Historica, 33(1), 157-182.

Wehdeking, V. (1971). The zero hour: Post-war literature's foundation in Germany (1945-1948). Stuttgart: Metzler.

Ziemke, E. F. (1990). The U.S. army in the occupation of Germany 1944-1946. Washington D.C.: Center of Military History United States Army.

Zink, H. (1957). The United States in Germany 1944-1945. New York: Van Nostrand Co. 